\title{
Interpersonal communication in medical profession on the example of physiotherapists
}

\begin{abstract}
Introduction. The article introduces the reader into the problem area, based on interpersonal relationships between physiotherapists and patients.

Aim. The aim of the study is to learn the factors determining the quality of physiotherapeutic services. The research was carried out in relation to verbal and non-verbal aspects of contact between physiotherapists and patients.

Material and method. The method used in the study was a quantitative survey based on a questionnaire.

Results. Ninety-six percent of respondents state that they have no problems with making interpersonal contact with patients. Fifty-three percent of them show interest in patients during the dialogue and the remaining group only initiates the contact and limits it to personal creativity. The research shows that the gender of the respondents does not significantly affect the ways of showing interest in patients. However, the length of service differentiates their approach to patients as well as the age of the patients themselves.

Discussion. Communication in a profession of physiotherapist refers to the personal preferences and interpersonal skills of the respondents, which can be determined by a specific style of their work. In addition, significantly it is determined by the level of education of future physical therapists, which was mentioned not only by the people in this study, but also in the studies cited in the literature included in the discussion.

Conclusions. The quality of physiotherapy services is determined not only by instrumental preparation of a physiotherapist but also by expression that results from the interpersonal contact. Physiotherapists are aware of building relationships during the first contact. Therefore, they try to make a positive impression. In such way, the quality of treatment can be increased.
\end{abstract}

Keywords: communication, physiotherapist, sociological research.

DOI: $10.2478 /$ pjph-2014-0028

\section{INTRODUCTION}

Due to the constantly increasing demand for rehabilitation services in modern medicine, a need has arisen to know the structure of the relationships between the physiotherapist and the patient. There is a very small number of publications on physiotherapists' communication skills [1,2], and therefore the selection of topics seems to be interesting to explore in order to improve the work of a physiotherapist. Each social role in medical professions also entails the significance of interpersonal contact $[3,4]$. Patients pay special attention to the expressive character of the relationship because they are unable to assess the instrumental aspect competently. Feelings about the patients' medical services implemented are largely determined by the emotions derived from interpersonal relationships [5]. When patients are talking about doctors, nurses, physiotherapist, in the first place they provide the characteristics of appearance: pleasant woman, elderly person, a big man, not pleasant but a specialist, sensitive, well-organized. The adjectives used for description and reflection are the effects of feelings that were provided to the patient during medical visits by the service provider [6-8]. The course of the relationship is influenced by factors influencing interpersonal communication, both those directly derived from the people as well as those that result from the arrangement of the medical office, objects - medical instruments used during the treatment process, the behavior of physiotherapists $[9,10]$. The characteristics of persons and places in the patients' descriptions intertwine because, depending on the degree of sensitivity of the patient and the expectations associated with the organization of the workplace provider, they are different for each patient. There are also different stereotypes among patients. Women believe that a male gynecologist is better than a female gynecologist is. Patients in the surgical professions react more positively to male doctors than to the female ones. The male physiotherapists are said to be more suitable for the profession, because the profession continues to be identified with the procedure of the massage. Communication will also be affected by clichés relating to such identifiers of professional

\footnotetext{
${ }^{1}$ School of Entrepreneurship and Marketing in Chrzanów, Poland

${ }^{2}$ Medical University of Silesia in Katowice, Poland
} 
role as the clothes and appearance. Therefore, a male nurse or a physiotherapist will often be perceived by patients as a doctor. While female doctors not carrying a stethoscope or without identifiers will be perceived as nurses [11].There are many definitions of the term "communication". Already in the $1950 \mathrm{~s}, \mathrm{R}$. Merton, the interpreter of mass communication, provided nearly one hundred and sixty of them. Today their number has increased several times. Charles Cooley, in his work created in 1894 "The Theory of Transportation" mentioned the term "communication" as the first one in the scientific literature. In this work, he describes communication as a mechanism that allows you to maintain and develop interpersonal relationships. He also notes that communication involves both facial expression, gestures, tone of voice, posture, as well as words and writing [12 ]. Wilbur Schramm describes however communication as a tool that distinguishes humans from other living beings. Also noteworthy is Defleur Melvin, who presented the approach to this issue as an act, which constitutes a means to express the group norms, allocation of roles, achieving coordination efforts, as well as the exercise of social control. We should also mention Garthie Jowett and Victoria O'Donnell, depicting communication as a situation in which one individual e.g. A, says to the other individual B about X [12]. All of the above mentioned theories are not mutually exclusive, only they highlight that communication is the process, exchange, but also a mutual reaction, exerting influence on the environment and its size is the result of different approaches to this phenomenon of presenting other elements [13-15]. In summary, communicating in a broad sense is a process designed to provide information, exchange of ideas, mutual sharing of knowledge, ideas by understanding the sender and the recipient. This process occurs at different levels, using different tools, and produces certain effects.

\section{AIM}

The aim of the study is to present the results of research on communication skills of physiotherapists, which was carried out at the turn of 2010/2011. The study included physiotherapists working in different workplaces, both in public and private medical offices. The main objective of the study was to examine the reasons causing difficulties in interpersonal relations, as well as what techniques the therapist uses to show the interest in patients. The work is an attempt to analyze these aspects of the relationships between the physiotherapist and the patient, which do not relate to medical issues but psychosocial quality of physiotherapy that determines the quality of physiotherapeutic services.

\section{MATERIAL AND METHODS}

The study was conducted among physiotherapists working in Silesia and Malopolska health centers, hospitals, and engaged in private practice settings. The study took place during a period of 1.10. 2010-31.01.2011.

\section{Characteristics of the study group.}

The research comprised 100 persons. The tested youngest person was 23 years old, and the oldest 59 years, of which $63 \%$ were women and $37 \%$ were men. Most of the surveyed people $(72 \%)$ were aged between 20 and 30 years of age, between 31 and 50 years of age there were $26 \%$ and only $2 \%$ of people were aged over 50 years. Most of the surveyed population came from the city $(87 \%)$. The countryside inhabitants accounted for $13 \%$. The largest group of respondents were maidens and bachelors (58\%) and $42 \%$ were married persons. The majority of respondents had higher education $(60 \%)$, higher vocational education or bachelor's degree $35 \%$. The diploma of rehabilitation technician was reported by $5 \%$ of respondents. The majority of respondents was employed in rehabilitation / health centers $(39 \%)$ and those running own private practice accounted for $38 \%$. The hospital employees constituted 33\%. Most of the surveyed people are working in a team (39\%), while 33\% work individually. The largest group are the people working for 5 years (72\%), and those with over 20 years' experience account for $7 \%$, with an experience of 10 years $-11 \%$ and $9 \%$ with the experience of about 15 years.

The study used a quantitative method and survey technique. The research tool was a questionnaire designed by the author. It consisted of questions relating to communication between physical therapist and patient, barriers to interpersonal communication, knowledge of the principles of good communication, approach to the patient by a physiotherapist.

\section{RESULTS}

The question "Do you easily establish contact with the patient?" was answered by the vast majority of respondents (96\%) positively. The remaining part, which constitutes $4 \%$, responded negatively. The majority of respondents believe the conversation to be the best way of showing interest in the patient. These people represent $53 \%$ of respondents. The second most frequently mentioned by the respondents way of showing interest to a patient, was asking questions. This statement was given by $38 \%$ of the respondents. The use of "medical language" which can be confusing for the patient is declared by $77 \%$ of the surveyed physical therapists, that is the majority, and $23 \%$ of the respondents answer this question negatively. The third, according to the number of answers is listening (34\%). Less important, by the respondents, is the eye contact $(17 \%)$, whilst the least - acquiescence $(8 \%)$. All the respondents felt that the conversation with a patient could alleviate the tension. Research shows that $42 \%$ of physiotherapists carry out a conversation with the patient in the gym. Conversations on the ward account for $35 \%$, and $38 \%$ take place in the office. The smallest number of consultations with a patient is carried out in the hallway $(7 \%)$. Forty-three percent of respondents spend up to 5 minutes on talking with a patient. Thirty-seven percent of physiotherapists talk with their patients for 5-10 minutes, while over 10 minutes is dedicated by $20 \%$ of the respondents and these more often are female physiotherapists. The data which relate to the for this activity significance of establishing good contact by a physiotherapist with the patient's family show that $83 \%$ of respondents consider it important, while $17 \%$ say the opposite. The correlation shows that the gender does not play a significant role in terms of making verbal contact. However, the differences are distinc- 
tive when taking into account the age of physiotherapists and the years of work experience. Definitely, the respondents with experience of less than five years of work ask questions more frequently, and those who have been working for about 15 years ask the least questions; they carry out a spontaneous conversation from which they draw conclusions and consequently develop methods of work. According to the respondents, patients present greater courage to senior-in-experience physiotherapists probably by feeling less anxious about themselves, while for medical workers, younger patients tend to be more skeptical. To the question: "Do you think the establishment of a good contact with a patient affects the quality of treatment?" the vast majority of respondents (94\%) gave an answer YES. The rest of the respondents, which accounts only for $6 \%$ of people, claimed NO. The question, which concerned non-verbal communication, resulted in $27.48 \%$ of respondents answering that they use maintaining the eye contact in order to establish a good relationship with a patient. The vast majority of respondents pay attention to maintaining the eye contact with a patient during the interview. These people represent $96 \%$ of the respondents, $4 \%$ do not pay attention to this aspect. Facial expression is used for this purpose by $20.53 \%$ of respondents, voice modulation by $18.54 \%$ of respondents. Consciously, $17.88 \%$ of the surveyed respondents maintain contact by body posture. The lowest percentage (15.56\%) use gestures . According to $92 \%$ of the respondents nonverbal communication is essential to establish proper contact with a patient, $8 \%$ of the respondents consider it irrelevant. The correlation shows that the gender significantly differentiates the eye contact among physiotherapists and as in everyday interpersonal relations women more often maintain constant eye contact while men compensate for the lack of the eye contact with the open body posture. Research globally shows that female physiotherapists care about the aesthetics of physical appearance, modulate voice intonation thus adjusting it to the patient's state of tension; although they do this consciously they only realized this fact during the study.

The vast majority of those surveyed (92\%) informs the patient what the therapeutic treatment will be based on, while the rest of the respondents $(8 \%)$ does not do this. It is the same group, which during the interview with the researcher denied the relevance of the process of non-verbal communication in maintaining contact between the physiotherapist and a patient. These respondents often have incomplete higher education - bachelor's degree. The data concerning the type of relationship to allow better results of rehabilitation show that $64 \%$ of respondents believe that establishing closer contact with a patient or a friendly relationship (informal contact), is more in favor of obtaining better results in the rehabilitation of the patient. The remaining respondents $(36 \%)$ believe that the only favorable contact is the formal one. During the research, respondents were asked if they had knowledge of the principles of interpersonal communication. The vast majority of the respondents $(85 \%)$ declare their knowledge of the principles of interpersonal relations. The remaining respondents, $(15 \%)$ confirm the absence of such knowledge. Compared with studies of other medical professions, physiotherapists are a group that has a very high level of awareness of the process of communication.
To the question: "What factors in your opinion can make communication with the patient more difficult?" a significant part of the respondents (86\%) gave a statement of the internal factors. External factors were indicated by $29 \%$ of respondents. The first included whether a person was open or closed to others or whether he or she liked his or her job and whether what they did had been learned and mechanical or practiced so many times that gave enough conviction. The external factors include the patient him/herself - whether he or she wants to cooperate or not; the workplace, the team of colleagues and most of all the equipment in the workplace.

The majority of respondents feel that the age of a patient has an impact on facilitating/hindering communication. These people represent $73 \%$ of respondents. The remaining respondents $(27 \%)$ believe that age does not affect the efficiency of communication. The correlation shows that both women and men perceive age as a factor in determining the quality of the course of physiotherapy services. To the question: "In your opinion, was the topic of interpersonal communication sufficiently discussed during your medical training?", $63 \%$ of respondents gave an answer YES. The remaining $36 \%$ of respondents stated NOT. One person representing $1 \%$ did not answer this question. In the respondents' opinion and in this case, primarily women, $66 \%$ of respondents believe that there should be more hours devoted to teaching the interpersonal communication, $33 \%$ of physiotherapists declare that it is not important. One person representing $1 \%$ did not answer this question. To the question: "What do you expect from patients?" - 35\% of respondents gave an answer - engagement in therapy. Equally high score was gained by cooperation, which was indicated by $30 \%$ of physiotherapists. Nineteen percent of respondents indicated sincerity/ providing reliable answers. The same number of people pointed out the obedience/adherence to the physiotherapist. The fifth score was gained by care $(13 \%$ of responses). Equally important by the respondents are confidence $(10 \%)$ and openness $(8 \%)$. Four percent of respondents answered neatness.

Summing up the obtained results, it can be concluded that physiotherapists show interest to patients at the level of verbal contact mainly by the use of conversation, asking questions and listening to the patient.

Physiotherapists are aware that the effect of the first contact builds relationships, this is why they try to make a positive impression and thus affect the whole therapy, including the quality of treatments. To establish a good contact with a patient, more than half of the respondents use non-verbal communication, consciously maintaining eye contact. Female physiotherapists modulate their voice to suit the patient's state of tension, although they discovered this fact only during the research. Men physiotherapists rarely look at the patients but listen carefully and take an open posture. Therapists insist on establishing closer contact with the patient, based on the expressive aspects of the relationship, devoid of formal framing. A large part of therapists declares knowledge of proper interpersonal communication. However, in their opinion, more attention should be paid to this issue during the training of physiotherapists. The main barriers to communication indicated by physiotherapists are the external factors such as noise, third parties taking part 
in the conversation who can interfere with the patient's sense of intimacy, as well as the lack of hygiene of patients undergoing physiotherapy treatments. The internal factors include the patient's age and condition of health. Involvement in therapy, collaboration, trust, are the most important expectations that physiotherapists expose to patients.

\section{DISCUSSION}

The research on the process of communication in the relations between the physiotherapist and the patient allowed for determining the importance of the rehabilitation process is the proper contact with the patient. The research was conducted by Magdalena Szumska from the Department of Management University of Economics and addressed the topic of communication in a hospital ward, in the light of evaluation of medical workers. Research shows that the main barriers in communication include too little time devoted to the patient $(79 \%)$ and introducing the patient with little information about his or her health (34\%) [16]. The analysis of the research can confirm that an important role in establishing and maintaining a good relationship with the patient is played by devoting appropriate amount of time for the patient. However, due to the large number of patients this contact is too short, which is confirmed by the study. According to $45 \%$ of the respondents, they spend hardly 5 minutes talking with a patient. Such amount of time may be insufficient even to stop at the bedside and obtain valuable information related to the condition of the patient's health, and even more, to establish normal relations with him/her. Test result of G. Bręczewski on "Perceptions of the rehabilitation staff on the level of anxiety in people with physical illness" prove satisfactory. The results of these studies indicate that the positive perception of physical therapists by patients is closely related to the amount of time spent by them at the bedside. This may prove a greater involvement of physiotherapists in the process of treatment compared with other medical staff [17]. Whereas Anna Włoszczak-Szubzda and Miroslaw J. Jarosz emphasize in their work the lack of training in terms of interpersonal communication in Polish higher education. In their opinion the education of medical students does not involve transferring of knowledge in the field of interpersonal communication, and it is only limited to the medical knowledge and technology. The authors of the study emphasize that the absence of compulsory education related to interpersonal communication leads to a situation in which the patient becomes only a medical case, devoid of psychological needs [18].The opinions of physiotherapists, gathered in our research material also confirm the need for increasing the number of classes related to the topic of interpersonal communication. This opinion is expressed by $66 \%$ of respondents. This confirms the thesis of the insufficient education of students in the field of interpersonal relations, empathy and principles of subjective treatment of a patient, which is reflected in the development of mature and compassionate attitudes. In her research, Gromadecka-Sutkiewicz discusses the matter of specific language that is the communication barrier signaled by patients. The above work shows that medical personnel commonly use the specialized medical language [19].
Moreover, this thesis has also been confirmed in studies conducted among physiotherapists, $77 \%$ of respondents indicated the use of specialized medical terminology. Satisfactory, however, is the fact that the majority of respondents tried to explain incomprehensible terms immediately. The issue that cannot be overlooked in the analysis of the collected research material is undoubtedly the influence of patient's age on the effectiveness of treatments. Both J.Szczepańska with co-authors and the presented research confirm that the establishment of positive interpersonal relations with older people, especially those hospitalized for a long time, deprived of their daily contact with the family, affects the effectiveness of the therapy [20]. Other research by these authors represent the view that the bad condition of the patients has a negative emotional impact on the process of improvement, which is associated with less commitment, motivation and the passive attitude of the patient with respect to actions taken [21]. Properly conducted interpersonal communication alleviates the stress of hospitalization or undergoing medical treatment. It affects the decrease of tension and reduces pain. Patients expect from a physiotherapist a friendly attitude, warmth, and increased sense of security, which is limited by disease and suffering [22].

The results confirm that the therapists in their actions try to fulfill these expectations, through listening to and conversation with the patient, often unrelated to the problems of a physical nature. An important role in the relations between the physiotherapist and the patient is played by non-verbal communication. The patient carefully observes the nonverbal behavior of a physiotherapist, which then he or she compares with what the physiotherapist says. The adequacy between verbal and non-verbal behavior gives the possibility to the development of honest atmosphere during the visit [23]. Another task for the physiotherapist is to also recognize and interpret non-verbal reactions of the patient.

\section{CONCLUSIONS}

Physiotherapists are aware that interpersonal contact significantly affects the relations so that they try to make a positive impression on the patient.

Various aspects of interpersonal contact between the physiotherapist and the patient are determined by the years of work experience and age of a patient followed by a physiotherapist's gender. The opinions of physiotherapists collected in our research material confirmed the need to increase the number of classes related to the topic of interpersonal communication in the education system.

Physiotherapists, in contrast to other medical professionals, have sensitivity to interpersonal contact with the patient, in particular touch.

\section{REFERENCES}

1. Augustynek A. Komunikacja interpersonalna. In: A. Augustynek (ed). Wstęp do psychologii. Warszawa: Difin; 2009. p. 14-122.

2. Olesch A. Rozmowa jak lek. Komunikacja pomiędzy lekarzem a pacjentem. Ogólnopol Prz Med. 2008;11:56-8.

3. Doroszewski J. Terapeutyczne znaczenie komunikacji między lekarzem a pacjentem. Med Metab. 2006;10(2):10-4. 
4. Tobiasz-Adamczyk B. Relacje lekarz-pacjent w perspektywie socjologii medycyny. Kraków: Wydawnictwo Uniwersytetu Jagiellońskiego; 2002.

5. Stewart J. Mosty zamiast murów. Podręcznik komunikacji interpersonalnej. Warszawa: Wydanie naukowe PWN; 2005.

6. Korulska E. Komunikacja interpersonalna. Dyrektor szkoły. 2005;11:IIVI.

7. Marcinowicz L. Sztuka rozmowy z pacjentem. Lek Rodz. 2004;9(2):2146.

8. Skotnicki AB. Relacja lekarz - pacjent. Med Metab. 2009;13(2):15-8.

9. Sikorski W. Bezsłowne komunikowanie w psychoterapii. Kraków: Wydawnictwo Impuls; 2010.

10. Cialdini R. Wywieranie wpływu na ludzi. Teoria i praktyka. Gdańsk: Gdańskie Wydawnictwo Psychologiczne; 1999.

11. Piasecka A. Komunikowanie wartości zdrowia w polskich kampaniach społecznych-wymiar edukacyjny. Toruń: Wydawnictwo Adam Marszałek; 2008.

12. Sztompka P. Socjologia. Kraków: Wydawnictwo Znak; 2002.

13. Barański J, Waszyński E. Komunikowanie się lekarza z pacjentem. Wrocław: Wydawnictwo Astrum; 2000.

14. Morreale S, Spitzberg H. Komunikacja między ludźmi. Warszawa: Wydawnictwo PWN; 2008.
15. Nęcki Z. Komunikacja międzyludzka. Kraków: Wydawnictwo Profesjonalnej Szkoły Biznesu; 1996.

16. Szumska M. Komunikacja z pacjentem na oddziale szpitalnym w świetle oceny lekarzy, pielęgniarek i pacjentów na przykładzie sześciu polskich szpitali. Pielęg Pol. 2005;2:430-4.

17. Bręczewski G. Spostrzeganie personelu rehabilitacyjnego a poziom lęku u osób z chorobami somatycznymi. Post Rehabil. 2001;15(4):75-83.

18. Wołoszczak-Szubza A, Jarosz M. Problemy komunikowania się personelu medycznego z pacjentami. Med Ogólna. 2008;14(3):225-34.

19. Dąbrowska K. W jakim kierunku zmierzają relacje pomiędzy lekarzem a pacjentem w Polsce? Pediatr Med Rodz. 2008;4(4):278-81.

20. Szczepańska J, Kowalska J, Greń G, Woźniewski M. Stosunek fizjoterapeutów do pacjentów w podeszłym wieku z zaburzeniami mentalnymi i behawioralnymi. Fizjoter Pol. 2006;6(3):216-21.

21. Szczepańska J, Greń G, Woźniewski M. Zaburzenia nastroju - istotny czynnik w procesie fizjoterapii osób w podeszłym wieku. Fizjoter Pol. 2008;8(2):170-8.

22. Gątkiewicz M, Motylewski S, Poziomska-Piatkowska E. Intonacja głosu w przekazie informacji między fizjoterapeutą a pacjentem na lekcji ruchu leczniczego - doniesienia wstępne. Post Rehabil. 2005;19(2):5-11.

23. Knapp H. Komunikacja w terapii. Warszawa: Wydawnictwo Naukowe PWN; 2009.

\section{Corresponding author}

Matyja Anna

7 Słowackiego Str., 32-660 Chełmek, Poland

tel: $600-629-612$

E-mail: matyjaanna@tlen.pl 